\title{
Meat quality of lambs fed phytogenic additives ${ }^{1}$
}

\section{Qualidade da carne de cordeiros alimentados com aditivos fitogênicos}

\author{
Nivea Maria Brancacci Lopes Zeola²; Américo Garcia da Silva Sobrinho; \\ Hirasilva Borba4; Laura Guilardi Giroto5; Julia Consolim Franhani5; \\ José Carlos Barbosa ${ }^{6}$
}

\section{Highlights}

As additives have been used in lamb diets, meat quality must be evaluated.

The inclusion of phytogenic additives was inefficient in reducing meat lipid oxidation.

Other phytogenic additive percentages must be evaluated to increase meat shelf life.

\section{Abstract}

The study was developed in the Sheep Production Laboratory of the Department of Animal Science, College of Agricultural and Veterinary Sciences, São Paulo State University, Jaboticabal, SP, Brazil. Thirtytwo non-castrated lle de France lambs weighing $20.0 \pm 0.2 \mathrm{~kg}$ received 4 diets with a roughage: concentrate ratio of 40: 60. The experimental treatments consisted of D1: corn silage + concentrate; D2: corn silage + concentrate $+30 \mathrm{mg}$ rosemary extract $\mathrm{kg}$ body weight ${ }^{1}$; D3: corn silage + concentrate $+30 \mathrm{mg}$ green tea extract kg body weight ${ }^{-1}$; and D4: corn silage + concentrate $+30 \mathrm{mg}$ oregano extract $\mathrm{kg}$ body weight ${ }^{-1}$, up to $35.0 \pm 0.2 \mathrm{~kg}$ body weight. The objectives were to evaluate rib eye area, cholesterol content, lipid oxidation, qualitative parameters, as well as perform sensory analysis, centesimal composition, and fatty acid profile of the meat. The experimental design was completely randomized with four treatments and eight replicates. The treatments were compared by Tukey's test through the SAS software (Statistical Analysis System Institute [SAS], 2003). Inclusion of phytogenic additives into the diets did not affect the qualitative parameters cholesterol content, lipid oxidation, and centesimal composition (except for protein content, which was lower in D2, 22.57\%, compared to D1, 25.62\%), as well as meat fatty acid profile (except for C18: $1 \mathrm{n} 7$ cis-vaccenic). The use of phytogenic additives provided suitable qualitative parameters.

1 First Author Post-Doctor Project.

2 Animal Science Researcher, CNPq Scholarship, Department of Animal Science, Faculdade de Ciências Agrárias e Veterinárias, FCAV, UNESP, Jaboticabal, SP, Brazil. E-mail: nivea.brancacci@ig.com.br

${ }^{3}$ AnimalScienceProf., DepartmentofAnimalScience,FCAV,UNESP, Jaboticabal,SP,Brazil.E-mail:americo.s.sobrinho@ unesp.br

${ }^{4}$ Animal Science Prof., Department of Technology, FCAV, UNESP, Jaboticabal, SP, Brazil. E-mail: hiras@fcav.unesp.br

${ }^{5}$ Animal Science Graduate Students, FCAV, UNESP, Jaboticabal, SP, Brazil. E-mail: lauguilardi@gmail.com; julia. consolim@gmail.com

${ }^{6}$ Animal Science Prof., Department of Exact Sciences, FCAV, UNESP, Jaboticabal, SP, Brazil. E-mail: jcbarbosa@fcav. unesp.br

* Author for correspondence

Received: Mar. 01, 2021 - Approved: Aug. 27, 2021 
Moreover, despite the well-known positive effect of antioxidants in the diet, phytogenic additive inclusion was ineffective in reducing lipid oxidation in lamb meat. However, further studies with different inclusion percentages should be carried out to find out how to increase shelf life without harming lamb qualitative parameters, especially regarding the sensory analysis.

Key words: Rosemary. Green tea. Oregano. Sheep. Qualitative parameters. Meat production..

\section{Resumo}

O trabalho foi realizado no Laboratório de Produção Ovina, pertencente ao Departamento de Zootecnia da FCAV, Unesp, Câmpus de Jaboticabal, SP. Trinta e dois cordeiros lle de France, machos não castrados, com 20,0 \pm 0,2 kg receberam 4 dietas, com relação volumoso:concentrado 40:60, sendo os tratamentos constituídos por D1: silagem de milho + concentrado, D2: silagem de milho + concentrado + $30 \mathrm{mg}$ de extrato de alecrim $\mathrm{kg}_{\text {peso }}$ corporal- $^{-1}$, D3: silagem de milho + concentrado $+30 \mathrm{mg}$ de extrato de chá verde $\mathrm{kg}$ de peso corporal ${ }^{-1}$ e D4: silagem de milho + concentrado $+30 \mathrm{mg}$ de extrato de orégano $\mathrm{kg}$ de peso corporal ${ }^{-1}$, até atingirem 35,0 $\pm 0,2 \mathrm{~kg}$ de peso corporal. Os objetivos foram avaliar a área de olho de lombo, o teor de colesterol, a oxidação lipídica, os parâmetros qualitativos, bem como a análise sensorial, a composição centesimal e o perfil de ácidos graxos da carne. O delineamento experimental foi o inteiramente casualizado, com quatro tratamentos e oito repetições, sendo as comparações entre as médias dos tratamentos feitas pelo teste Tukey a $5 \%$, e as análises de variância conforme procedimentos do SAS Software (Statistical Analysis System Institute [SAS], 2003). A inclusão de aditivos fitogênicos na dieta de cordeiros não afetou os parâmetros qualitativos da carne, o teor de colesterol, a oxidação lipídica e a composição centesimal (com exceção do teor de proteína que foi menor na D2, 22,57\%, em relação à D1, de 25,62\%) e o perfil de ácidos graxos (com exceção do C18:1n7 cis-vacênico). O uso dos aditivos fitogênicos na dieta dos cordeiros propiciou adequadas características qualitativas da carne ovina, e apesar do conhecido efeito positivo do uso de antioxidantes na dieta de cordeiros, a inclusão dos aditivos fitogênicos não foi eficaz em reduzir a oxidação lipídica da carne, entretanto, novos estudos com diferentes porcentagens de inclusão devem ser conduzidos para averiguar como aumentar a vida de prateleira da carne sem prejudicar as características qualitativas da carne, principalmente em relação à análise sensorial.

Palavras-chave: Alecrim. Chá verde. Orégano. Ovinos. Parâmetros qualitativos. Produção de carne.

\section{Introduction}

Brazil is among the 20 major small ruminant producers worldwide, occupying the $18^{\text {th }}$ position in the ranking (Zen, Santos, \& Monteiro, 2014). According to the Food and Agriculture Organization of the United Nations [FAOSTAT] (2019), the Brazilian sheep herd has 19.71 million heads, with 6.09 million heads being slaughtered, and meat production of 97,545 tons. Despite this magnitude, lamb meat demands are greater than the supplies. Therefore, lamb meat production must increase throughout the year to meet consumer market demands properly.

Lambispotentiallyahigheracceptability category given its meat characteristics such as less fat, greater tenderness, and milder aroma than has meat from adult animals. Lamb termination in feedlots to increase good quality 
meat production has been a satisfactory system. Such management aims to maximize the genetic potential of animals by balancing rations, thus improving animal performance, finishing, and carcass standardization (Zanette \& Neumann, 2012).

The meat chain has undergone major scientific and technological changes to enhance meat quality for enlightened consumers willing to pay for it. A few years ago, the goal was to produce meat products in quantity and at minimum costs, whereas today the composition and quality of the final product are more interesting. This is because nowadays food not only has a nourishing function but also provides other benefits to consumers (Augustini et al., 2015).

In this sense, the use of phytogenic additives in nutrition and animal feed has benefits to the human-animal-environment triad, as a strategy to improve feed efficiency. Allied to this is the growing consumer demand for organically produced animal products. Therefore, natural products that do not pose risks to human health and can improve nutrition and animal production have increased in interest (Sallam, Abdelgaleil, \& Bueno, 2011).

As an alternative to prevent food oxidative deterioration and ensure its innocuousness, the use of antioxidant compounds is effective since these substances can prevent, delay, remove, or even protect cells from oxidative damages (Pamplona \& Constantini, 2011). In this context, the search for natural compounds with antioxidant capacity has been the subject of research. Natural antioxidants are formed by vitamins, minerals, enzymes, pigments, essential oils, and other plant compounds. All of them have the function of inhibiting the effect of free radicals, which are highly unstable molecules with an odd number of electrons and, to achieve stability, they acquire electrons by reacting with neighboring compounds, oxidizing them.

Among natural options, rosemary (Rosmarinus officinalis), green tea (Camellia sinensis), and oregano (Origanum vulgare) plant extracts have aroused interest among researchers for their antioxidant activity (Bañón, Méndez, \& Almeida, 2012; Jiang \& Xiong, 2016), with rosemary being considered the most abundant source of carnosic acid in quantitative terms (Birtic, Dussort, Pierre, Bily, \& Roller, 2015).

Therefore, this study aimed to evaluate the effect of adding three antioxidant sources (rosemary extract [source of carnosic acid], green tea extract [source of catechins], and oregano extract [source of carvacrol]) into the diet of lle de France lambs on quantitative carcass parameters (yields of hot and cold carcass, and weight loss by cooling), meat qualitative traits $(\mathrm{pH}$, temperature, color, waterholding capacity, water loss per thawing, cooking losses, shear force, number of reactive substances to 2-thiobarbituric acid, and sensory analysis), centesimal composition (moisture, protein, fat, and minerals), fatty acid profile, and cholesterol contents.

\section{Material and Methods}

The experiment was developed at the College of Agricultural and Veterinary Sciences, FCAV, UNESP, Campus of Jaboticabal, SP (Brazil). It was approved by the Ethics Committee on Animal Use of the institution, under protocol no. 004159/18, on April 19, 2018. 
Feedlot and slaughter of lambs, as well as evaluations of $\mathrm{pH}$, temperature, color, water-holding capacity, water loss by thawing, cooking weight losses, and sheep meat shear force were carried out in the Sheep Production Laboratory, while food chemicalbromatological analyses at the Animal Nutrition Laboratory, both belonging to the Department of Animal Science. The analyses of cholesterol, lipid oxidation, centesimal composition, fatty acid composition, and Longissimus muscle sensory attributes were carried out at the Animal Products Technology Laboratory, which belongs to the Technology Department of the same institution.

Thirty-two lle de France lambs were used in the performance trial. They were freshly weaned at about 45 days of age and $20 \pm 0.2$ $\mathrm{kg}$ of body weight. The animals were housed in individual pens, measuring about $1.0 \mathrm{~m}^{2}$, with a slatted and suspended floor, equipped with individual feeders and water drinkers installed in covered sheds. The lambs were identified, dewormed, vaccinated against clostridiosis, and remained 14 days in a pre-experimental period. Then, they were weighed every 14 days at 7:00 AM, when haemonchosis was also monitored using the Famacha ${ }^{\circledR}$ method (Van Wyk \& Bath, 2002).
The experimental diets (Table 1) were formulated to meet the requirements of weaned lambs, as recommended by the National Research Council [NRC] (2007) for an average weight gain of $300 \mathrm{~g} \mathrm{day}^{-1}$. During the feedlot phase, the amounts of additives were weekly adjusted as a function of animal body weight (BW), receiving $30 \mathrm{mg}$ additive daily per ${ }^{-1 \mathrm{~kg}}$ of /BW, which was subdivided into two fractions, having received an average of $0.78 \mathrm{~g}^{\text {-1additive. }}{ }^{-1}$ day throughout the feedlot experiment.

The forage: concentrate ratio in diets was 40: 60. Treatments consisted of D1: corn silage + concentrate, D2: corn silage + concentrate $+30 \mathrm{mg}$ rosemary extract $\mathrm{kg}^{-1}$ body weight (carnosic acid source), D3: corn silage + concentrate $+30 \mathrm{mg}$ green tea extract $\mathrm{kg}^{-1}$ body weight (source of catechins), and D4: corn silage + concentrate $+30 \mathrm{mg}$ oregano extract $\mathrm{kg}^{-1}$ body weight (source of carvacrol). The concentrate (Table 1) was composed of ground corn, soybean bran, dicalcium phosphate, calcite limestone, mineral and vitamin supplements, leaving the diets with similar protein and energy contents. The diets were provided at 7:00 AM and 5:00 PM to allow at least $10 \%$ leftovers, which were collected daily, weighed, and subtracted from the total amount of food provided to quantify consumption.

\section{Table 1}

Percentage, chemical-bromatological, and main fatty acid compositions of the experimental diets*.

Composition

Ingredient (\%DM)

Corn silage

Ground corn kernels

Soybean meal

\section{Experimental diet}

D1

D2

D3

D4

$\begin{array}{llll}40.00 & 40.00 & 40.00 & 40.00 \\ 40.53 & 40.53 & 40.53 & 40.53 \\ 17.88 & 17.88 & 17.88 & 17.88\end{array}$

continue... 
contuation...

\begin{tabular}{|c|c|c|c|c|c|}
\hline \multicolumn{2}{|c|}{ Dicalcium phosphate } & 0.18 & 0.18 & 0.18 & 0.18 \\
\hline \multicolumn{2}{|c|}{ Calcite limestone } & 0.41 & 0.41 & 0.41 & 0.41 \\
\hline \multicolumn{2}{|c|}{ Mineral and vitamin supplements ${ }^{1}$} & 1.00 & 1.00 & 1.00 & 1.00 \\
\hline \multicolumn{6}{|c|}{ Additives (mg kg BW-1) } \\
\hline \multicolumn{2}{|c|}{ Rosemary extract } & - & 30 & - & - \\
\hline \multicolumn{2}{|c|}{ Green tea extract } & - & - & 30 & - \\
\hline \multicolumn{2}{|c|}{ Oregano extract } & - & - & - & 30 \\
\hline \multicolumn{6}{|c|}{ Chemical-bromatology } \\
\hline \multicolumn{2}{|c|}{ Dry matter (DM) } & 65.90 & 65.90 & 65.90 & 65.90 \\
\hline \multicolumn{2}{|c|}{ Crude protein $(\mathrm{CP})^{2}$} & 15.20 & 15.20 & 15.20 & 15.20 \\
\hline \multicolumn{2}{|c|}{ Ethereal extract (EE)² } & 3.30 & 3.30 & 3.30 & 3.30 \\
\hline \multicolumn{2}{|c|}{ Neutral detergent fiber (NDF) ${ }^{2}$} & 29.20 & 29.20 & 29.20 & 29.20 \\
\hline \multicolumn{2}{|c|}{ Acid detergent fiber (ADF) ${ }^{2}$} & 15.30 & 15.30 & 15.30 & 15.30 \\
\hline \multicolumn{2}{|c|}{ Digestible energy (Mcal kg DM-1 ${ }^{-1}$} & 2.83 & 2.83 & 2.83 & 2.83 \\
\hline \multicolumn{6}{|c|}{ Fatty acid } \\
\hline Capric & C10:0 & 0.01 & 0.01 & 0.01 & 0.01 \\
\hline Lauric & C12:0 & 0.07 & 0.07 & 0.07 & 0.07 \\
\hline Myristic & C14:0 & 0.10 & 0.10 & 0.10 & 0.10 \\
\hline Pentadecanoic & C15:0 & 0.03 & 0.03 & 0.03 & 0.03 \\
\hline Palmitic & C16:0 & 14.75 & 14.75 & 14.75 & 14.75 \\
\hline Palmitoleic & C16:1 & 0.14 & 0.14 & 0.14 & 0.14 \\
\hline Heptadecanoic & C17:0 & 0.12 & 0.12 & 0.12 & 0.12 \\
\hline Heptadecenoic & C $17: 1$ & 0.03 & 0.03 & 0.03 & 0.03 \\
\hline Stearic & C18:0 & 3.19 & 3.19 & 3.19 & 3.19 \\
\hline Oleic & $\mathrm{C} 18: 1 \mathrm{n} 9 \mathrm{c}$ & 26.11 & 26.11 & 26.11 & 26.11 \\
\hline Cis-vaccenic & C18:1n7 & 0.77 & 0.77 & 0.77 & 0.77 \\
\hline Linoleic & C18:2n6c & 49.80 & 49.80 & 49.80 & 49.80 \\
\hline y linolenic & C18:3n6 & 0.18 & 0.18 & 0.18 & 0.18 \\
\hline$\alpha$ linolenic & C18:3n3 & 3.35 & 3.35 & 3.35 & 3.35 \\
\hline Arachidonic & C 20:0 & 0.53 & 0.53 & 0.53 & 0.53 \\
\hline Eicosenoic & C20:1n9 & 0.21 & 0.21 & 0.21 & 0.21 \\
\hline Eicosadienoic & $\mathrm{C} 20: 2$ & 0.02 & 0.02 & 0.02 & 0.02 \\
\hline Behenic & C22:0 & 0.28 & 0.28 & 0.28 & 0.28 \\
\hline Tricosanoic & C23:0 & 0.04 & 0.04 & 0.04 & 0.04 \\
\hline Lignoceric & C24:0 & 0.27 & 0.27 & 0.27 & 0.27 \\
\hline
\end{tabular}

${ }^{1}$ Warranty levels per $\mathrm{kg}$ of the product: calcium $120 \mathrm{~g}$, chlorine $90 \mathrm{~g}$, sodium $62 \mathrm{~g}$, magnesium $54 \mathrm{~g}$, phosphorus $50 \mathrm{~g}$, sulfur 34g, zinc $1600 \mathrm{mg}$, manganese $1500 \mathrm{mg}$, iron 1064mg, fluoride (Max.) 730mg, copper 50mg, iodine 25mg, cobalt 10mg, vitamin D3 40,000 IU; ${ }^{2} \%$ in DM; D1: corn silage + concentrate; D2: corn silage + concentrate + 30 mg rosemary extract kg BW ${ }^{-1}$; D3: corn silage + concentrate $+30 \mathrm{mg}$ green tea extract kg BW ${ }^{-1}$; D4: corn silage + concentrate +30 $\mathrm{mg}$ oregano extract $\mathrm{kg} \mathrm{BW}^{-1} ; \mathrm{BW}=$ body weight. ${ }^{*}$ These calculations were performed with silage and the ingredients contained in the concentrate of diets, without inclusion phytogenic additives. 
Lambs were slaughtered when they reached $35.0 \pm 0.2 \mathrm{~kg}$ body weight after 16-h solid fasting. The animals were stunned using a TEC 10-PC concussion pistol, sectioning the jugular veins and carotid arteries for bleeding, followed by evisceration and removal of the head and extremities of the limbs, according to humane slaughter procedures. After slaughter, the carcasses remained in a cold room at $6^{\circ} \mathrm{C}$ for 24 hours hung by the Gastrocnemius tendons on appropriate hooks, with the ends spaced $17 \mathrm{~cm}$ apart.

Lamb meat was evaluated for $\mathrm{pH}$, temperature, and color in triplicate 45 minutes and 24 hours after slaughter. The $\mathrm{pH}$ was measured by a Testo-205 digital $\mathrm{pH}$ meter coupled to a penetration electrode (CIELAB system). The color was measured with the aid of a Minolta CR-400 colorimeter (illuminant D65) calibrated to a white standard, which determines the coordinates $L^{*}$ (brightness, $a^{*}$ (red intensity), and $b^{*}$ (yellow intensity). Color measurements were taken thirty minutes after sectioning for exposure of myoglobin to oxygen, according to the method of Cañeque and Sañudo (2000).

Afterward, the carcasses were split into two halves, with the left part being divided into five anatomical regions: neck, shoulder, ribs, loin, and leg (Silva, 2008). Maximum width (measurement $A$ ) and maximum depth (measurement B) of the Longissimus muscle were measured at the $13^{\text {th }}$ rib height; minimum and maximum fat thickness were also measured over the Longissimus muscle (measurements $\mathrm{C}$ and $\mathrm{GR}$ ) at the 13th rib, with the second being measured $11 \mathrm{~cm}$ apart from the midline (Silva, Kadim, \& Purchas, 2003). Lastly, the ribeye area was calculated using the following formula: $(A / 2 \times B / 2) \pi$.

For meat qualitative evaluation,
Longissimus muscle samples were individually vacuum-packed, identified, and frozen at $-18^{\circ} \mathrm{C}$ until analyses. The qualitative parameters analyzed comprised cholesterol contents, number of substances reactive to 2-thiobarbituric acid, water-holding capacity, water loss by thawing, cooking losses, shear force, centesimal composition (moisture, protein, fat, and minerals), fatty acid profile, as well as sensory traits.

Cholesterol content was determined according to the procedure of Bohac, Rhee and Ono (1988), adapted by Bragagnolo and Rodriguez-Amaya (2001). Yet for lipid oxidation, we used the method described by Pikul, Leszczynski and Kummerow (1989).

The method of Koohmaraie, Shackelford and Wheeler (1998) was used to determine water loss by thawing, while that described by Hamm (1986) was used for water holding capacity. For cooking weight loss (CWL), samples were previously weighed and then cooked in an electric grill (George Foreman - GBZ4C model) preheated to $170^{\circ} \mathrm{C}$. During the cooking, temperatures at the geometric center of samples were monitored with the aid of thermocouples until reaching $71^{\circ} \mathrm{C}$. Then, the samples were removed from the grill and weighed again after reaching a cooling room temperature, for later CL calculation in percentage. Thereafter, 1.27-cm-diameter cylindrical samples were removed parallel to muscle fiber orientation (Wheeler \& Koohmaraie, 1999) for shear force measurements using a Texture Analyzer apparatus (Brookfield - CT3 10K model), coupled to a $1.016 \mathrm{~mm}$ thick Warner-Bratzler blade, with values expressed in kgf.

After lyophilization of muscle samples, centesimal composition analysis (moisture, protein, fat, and minerals) was performed following recommendations of the Association 
of Official Analytical Chemists [AOAC] (1995). For fatty acid profile, lipids were extracted from meat according to the method by Bligh and Dyer (1959), and fatty acid esters were isolated according to the technique of Hartman and Lago (1973) and analyzed in a gas chromatograph (Shimadzu - model GC14B).

Saturated (SFA), unsaturated (UFA), monounsaturated(MSFA), and polyunsaturated (PSFA) fatty acids, as well as some ratios between them (UFA: SFA, MSFA: SFA, and PSFA: SFA), were quantified from the fatty acid profile. Fatty acids were classified according to functionality in hypocholesterolemic (h), and hypercholesterolemic $(\mathrm{H})$, as described by Bessa (1999). The indexes atherogenicity (Al) and thrombogenicity $(\mathrm{TI})$ were also calculated according to Ulbricht and Southgate (1991), and activities of $\Delta 9$-desaturases (16 and 18) and elongase enzymes according to MalauAduli, Siebert, Bottema and Pitchford (1997). The sensory analysis followed the method described by Moraes (1993), with a nine-point structured hedonic scale wherein: 1- really disliked it, 2- I disliked it a lot, 3- I disliked it regularly, 4- I disliked it slightly, 5- indifferent, 6- I liked it slightly, 7- I liked it regularly, 8- I liked it a lot, and 9- I liked it very much.

\section{Results and Discussion}

Cholesterol levels and lipid oxidation in the Longissimus muscle of lamb meat (Table 2) were not influenced by the inclusion of phytogenic additives, averaging $94.23 \mathrm{mg}$ cholesterol $100 \mathrm{~g}^{-1}$ meat and $1.03 \mathrm{mg}$ malondialdehyde (MDA) $\mathrm{kg}^{-1}$ meat, respectively. Conversely, Morán et al. (2013) evaluated diets with and without the addition of $0.6 \mathrm{~g}$ carnosic acid $\mathrm{kg}^{-1}$ feed concentrate of lambs between 15 and $25 \mathrm{~kg}$ body weight and found that meat from lambs fed $0.6 \mathrm{~g}$ of carnosic acid $\mathrm{kg}^{-1}$ feed concentrate had greater oxidative stability compared to the control treatment.

\section{Table 2}

Measurements in Longissimus muscle (A, B, C, and GR) of cholesterol content and lipid oxidation of meat from Ile de France lambs fed diets with and without phytogenic additives.

\begin{tabular}{|c|c|c|c|c|c|c|c|}
\hline \multirow{2}{*}{ Composition } & \multicolumn{4}{|c|}{ Experimental diet } & \multirow{2}{*}{ F } & \multirow{2}{*}{$\operatorname{Pr}>F$} & \multirow{2}{*}{ CV (\%) } \\
\hline & D1 & D2 & D3 & D4 & & & \\
\hline$A(\mathrm{~cm})$ & 5.54 & 5.68 & 5.53 & 5.82 & 0.35 & 0.7875 & 8.93 \\
\hline $\mathrm{B}(\mathrm{cm})$ & 2.89 & 3.25 & 3.27 & 3.05 & 2.29 & 0.1235 & 7.94 \\
\hline $\mathrm{C}(\mathrm{mm})$ & 3.01 & 3.03 & 3.55 & 2.92 & 0.71 & 0.5600 & 23.81 \\
\hline $\mathrm{GR}(\mathrm{mm})$ & 7.30 & 4.78 & 7.12 & 6.96 & 0.66 & 0.5890 & 44.72 \\
\hline Area (cm2) & 12.56 & 14.50 & 14.26 & 14.01 & 0.78 & 0.5255 & 14.35 \\
\hline Cholesterol (mg.100g-1 meat) & 90.47 & 99.41 & 89.40 & 97.63 & 3.33 & 0.0505 & 6.18 \\
\hline Lipidic oxidation (mg.MDA kg-1 meat) & 1.02 & 1.07 & 1.04 & 0.98 & 1.67 & 0.2184 & 6.39 \\
\hline
\end{tabular}

D1: corn silage + concentrate; D2: corn silage + concentrate + 30 mg rosemary extract kg $\mathrm{BW}^{-1}$; D3: corn silage + concentrate $+30 \mathrm{mg}$ green tea extract kg BW-1; $\mathrm{D} 4$ : corn silage + concentrate +30 mg oregano extract kg BW ${ }^{-1} ; \mathrm{A}^{-}$ maximum width of Longissimus muscle; $\mathrm{B}$ - maximum depth of Longissimus muscle; $\mathrm{C}$ - minimal thickness of covering fat over the Longissimus muscle; GR - maximum thickness of covering fat over the loin profile ( $11 \mathrm{~cm}$ from the midline); Longissimus muscle area $=(\mathrm{A} / 2 \times \mathrm{B} / 2) \pi$; Lipid oxidation - number of substances reactive to 2-thiobarbituric acid; MDA - malondialdehyde. 
Justo and Moraes (2008) evaluated the antioxidant potential of active plant extracts and concluded that rosemary extract addition could prevent oxidative deterioration in various systems by reducing free radicals, showing high potential as a substitute for synthetic antioxidants in the chemical, pharmaceutical, and food industries. According to Bañón et al. (2012), lamb diets supplemented with rosemary extract were effective in prolonging the shelf life of meat cuts, inhibiting lipid oxidation, rancidity, and microbial deterioration.

Nieto, Díaz, Bañón and Garrido (2010) reported that the meat of lambs born to ewes fed distilled rosemary leaves have lower lipid oxidation, lower total microorganism count, and higher color stability during 21 days of storage under retail display conditions. According to the same authors, rosemary leaves are a good alternative to synthetic additives in diets and, according to Bañón et al. (2012), the dietary use of rosemary extracts in lambs seems to be promising for improving meat quality aspects.

However, as shown in our study (Table 2) wherein phytogenic additives did not affect lamb meat lipid oxidation, averaging $1.04 \mathrm{mg}$ MDA kg ${ }^{-1}$ meat, Aouadi et al. (2014) studied the inclusion of $400 \mathrm{mg}$ rosemary essential oil kg-1 $\mathrm{DM}$ in the diet of Barbarine lambs slaughtered at 6 months of age, they found no differences between the control (without extract) and the treatment including rosemary essential oil, averaging $2.69 \mathrm{mg} \mathrm{MDA} \mathrm{kg}^{-1}$ meat.

Yagoubi et al. (2018) found differences in meat lipid oxidation values for Barbarine lambs slaughtered at 13 months of age, averaging $35.0 \mathrm{~kg}$ body weight, and receiving pellets containing 60 and $87 \%$ of rosemary distillation residues. After six days of storage, the authors observed that lamb meat of animals receiving rations containing rosemary residues showed values from 1.0 to $1.5 \mathrm{mg}$ MDA $\mathrm{kg}^{-1}$ meat compared to the control, which had values above $2.5 \mathrm{mg} \mathrm{MDA} \mathrm{kg}^{-1}$ meat; however, this situation had not been observed for fresh meat, in which values lower than 1.5mg MDA $\mathrm{kg}^{-1}$ meat were detected for all treatments.

Simitzis et al. (2008) observed that incorporation of oregano essential oil in lamb diets has a strong antioxidant effect on meat, delaying lipid oxidation and having a positive effect on meat coloration during refrigerated storage and long-term freezing. However, there are few studies with oregano plant extract, hence further research should be developed.

Bellés, Alonso, Roncalés and Beltrán (2017) described that oregano and rosemary addition to lamb diets reduced lipid oxidation in steaks stored at $1^{\circ} \mathrm{C}$ for 13 days compared to the control. However, these authors also highlighted that the use of essential oils and/ or extracts may have adverse effects on sensory parameters. Depending on the concentration used, meat flavor or odor can be intensified, changing the original product, and generating consumer rejection. Therefore, sensory analysis is important in studies of this nature.

Lamb meat $\mathrm{pH}$ (Table 3) was not influenced by dietary additive inclusion, with averages of 6.55 and 5.56 for 45 minutes and 24 hours after slaughter, respectively. Sheep meat normally reaches a final $\mathrm{pH}$ between 5.5 and 5.8 within 12 and 24 hours after slaughter, as observed here ( $\mathrm{pH}$ of 5.56). Notably, although some extrinsic factors, such as food type and fasting time, have potential influences, meat $\mathrm{pH}$ is mostly affected by muscle glycogen content, which favors lactic acid formation, lowering $\mathrm{pH}$ and making meat softer and juicier, with a slightly acidic taste and characteristic odor. 
The $\mathrm{pH}$ values found in our study can be considered adequate. Moreover, once normal values of meat $\mathrm{pH}$ drop are found, other qualitative parameters, such as water holding capacity, color, and tenderness, may also be appropriate.

\section{Table 3}

Measurements of $\mathrm{pH}$, temperature $\left({ }^{\circ} \mathrm{C}\right)$, and color $\left(\mathrm{L}^{*}, \mathrm{a}^{*}\right.$, and $\left.\mathrm{b}^{*}\right)$ of meat from lle de France lambs fed diets with and without phytogenic additives.

\begin{tabular}{|c|c|c|c|c|c|c|c|}
\hline \multirow{2}{*}{ Parameter } & \multicolumn{4}{|c|}{ Experimental diet } & \multirow{2}{*}{$\mathrm{F}$} & \multirow{2}{*}{$\operatorname{Pr}>\mathrm{F}$} & \multirow{2}{*}{ CV (\%) } \\
\hline & D1 & D2 & D3 & D4 & & & \\
\hline \multicolumn{8}{|c|}{45 minutes after slaughter } \\
\hline pH & 6.66 & 6.42 & 6.56 & 6.57 & 1.94 & 0.1702 & 2.19 \\
\hline Temperature $\left({ }^{\circ} \mathrm{C}\right)$ & 38.38 & 38.74 & 38.05 & 38.23 & 0.59 & 0.6345 & 2.08 \\
\hline \multicolumn{8}{|c|}{24 hours after slaughter } \\
\hline $\mathrm{pH}$ & 5.51 & 5.59 & 5.52 & 5.62 & 2.67 & 0.0881 & 1.19 \\
\hline Temperature $\left({ }^{\circ} \mathrm{C}\right)$ & 8.09 & 8.02 & 8.11 & 8.17 & 0.19 & 0.9030 & 3.49 \\
\hline \multicolumn{8}{|l|}{ Color } \\
\hline \multicolumn{8}{|c|}{45 minutes after slaughter } \\
\hline$L^{*}$ & 34.59 & 34.19 & 35.02 & 33.93 & 0.16 & 0.9192 & 7.52 \\
\hline$a^{*}$ & 15.11 & 15.40 & 15.55 & 14.66 & 0.21 & 0.8898 & 12.48 \\
\hline$b^{*}$ & 3.58 & 3.97 & 3.38 & 3.21 & 0.95 & 0.4433 & 19.89 \\
\hline \multicolumn{8}{|c|}{24 hours after slaughter } \\
\hline$L^{*}$ & 42.01 & 40.25 & 39.61 & 41.78 & 0.54 & 0.6627 & 8.33 \\
\hline$a^{*}$ & 17.68 & 18.11 & 20.24 & 18.25 & 0.53 & 0.6667 & 18.14 \\
\hline$b^{*}$ & 5.79 & 7.35 & 7.81 & 7.34 & 0.96 & 0.4397 & 26.01 \\
\hline \multicolumn{8}{|c|}{ After thawing } \\
\hline$L^{*}$ & 45.44 & 44.44 & 45.25 & 45.36 & 0.19 & 0.8991 & 4.66 \\
\hline$a^{*}$ & 17.62 & 19.64 & 18.51 & 18.51 & 0.58 & 0.6357 & 11.71 \\
\hline$b^{*}$ & 6.41 & 7.25 & 6.63 & 5.88 & 0.89 & 0.4685 & 19.36 \\
\hline
\end{tabular}

D1: corn silage + concentrate; D2: corn silage + concentrate + 30 mg rosemary extract kg BW-1; D3: corn silage + concentrate $+30 \mathrm{mg}$ green tea extract kg BW-1; D4: corn silage + concentrate +30 mg oregano extract kg BW-1; ${ }^{*}-$ luminosity; $a^{*}$ - redness; $b^{*}$ - yellowness. 
When researching the effect of including green tea $\left(2,4\right.$, and $\left.6 \mathrm{~g} \mathrm{~kg}^{-1} \mathrm{DM}\right)$ in the feed of 3-month-old Ujumqin lambs, Zhong et al. (2015) found that, after 24 hours of slaughter, meat $\mathrm{pH}$ was not influenced by treatments, averaging 5.48 .

In a study to verify the effect of including rosemary distillation residues at proportions of 60 and $87 \%$ into pellets supplied to Barbarine lambs slaughtered at 13 months of age, with an average body weight of $35.0 \mathrm{~kg}$, Yagoubi et al. (2018) also did not observe differences in the final $\mathrm{pH}$ of the evaluated lamb meat in Longissimus thoracis muscle, with a value of 5.45 .

Likewise, lamb meat color 45 minutes and 24 hours after slaughtering and thawing was not affected by the inclusion of phytogenic additives. The color parameters $L^{*}, a^{*}$, and $b^{*}$ after 45 minutes were 34.43 , 15.18, and 3.53; after 24 hours of slaughter were $40.91,18.57$, and 6.54 ; and after thawing were 45.12, 18.57, and 6.54 (Table 3). Souza et al. (2004) reported that the color parameters of sheep meat range from 31.36 to 38.0 for $L^{*}$, from 12.27 to 18.01 for $a^{*}$, and from 3.34 to 5.65 for $b^{*}$. Therefore, our findings were higher than those described by Souza et al. (2004). The $L^{*}$ values are commonly higher in lamb meats as they have more water and less fat than older sheep. These, in turn, have the meat centesimal composition modified, with greater fat deposition and lower water content in muscle tissue, leading to darker meat colors (low L*).

Still, on meat color, we found that treatments did not affect the parameters $L^{*}, a^{*}$, and $b^{*}$ under any of the evaluated conditions (45 minutes and 24 hours after slaughter and thawing). Aouadi et al. (2014) also noted that inclusion of $400 \mathrm{mg}$ rosemary essential oil $\mathrm{kg} \mathrm{DM}^{-1}$ in diets of 6-month-old Barbarine lambs did not differ from the control (without rosemary), with meat color values of 46.63 , 16.32, and 14.37 for $L^{*}, a^{*}$ and $b^{*}$, respectively. In our study, meat color parameters after thawing were $L^{*}$ of 45.12 , a* of 18.57 , and $b^{*}$ of 6.54 (Table 3). These results corroborate those of $p$ Zhong et al. (2015) on the effect of green tea inclusion $\left(2,4\right.$, and $\left.6 \mathrm{~g} \mathrm{~kg}^{-1} \mathrm{DM}\right)$ in diets of Ujumqin lamb at 3 months of age; these authors found no differences in lamb meat color in terms of luminosity (32.59) and red content (14.17) but observed yellow contents of 4.21, 4.50, and 4.32 after increasing inclusions.

Likewise, Yagoubi et al. (2018) found differences in the yellowness of the meat from Barbarine lambs slaughtered at 13 months of age and with an average body weight of $35.0 \mathrm{~kg}$. These animals had received pellets with 60 and $87 \%$ rosemary distillation residue inclusion and had yellowness values of 11.86 for the control (without inclusion) and of 14.85 for treatments with 60 and $87 \%$ inclusion, which did not differ from each other. As for luminosity and redness, these authors reported no effect of treatments, obtaining values of 34.70 and 8.70 , respectively.

Table 4 shows that weight losses after thawing and cooking, as well as shear force, were not affected by additions of additives to lamb diets, with values of $3.29 \%, 31.00 \%$, and 3.46 kgf, respectively. However, water-holding capacity differed $(\mathrm{P}<0.05)$ among treatments, with the highest value for oregano extract (60.40\%), which did not differ $(P>0.05)$ from green tea and control. 
Table 4

Qualitative parameters and centesimal composition $\left(\mathrm{g}^{\left.100 \mathrm{~g}^{-1}\right)}\right.$ of meat from lle de France lambs fed diets with and without phytogenic additives.

\begin{tabular}{|c|c|c|c|c|c|c|c|}
\hline \multirow{2}{*}{ Parameter } & \multicolumn{4}{|c|}{ Experimental diet } & \multirow{2}{*}{$\mathrm{F}$} & \multirow{2}{*}{$\operatorname{Pr}>\mathrm{F}$} & \multirow{2}{*}{ CV $(\%)$} \\
\hline & D1 & D2 & D3 & D4 & & & \\
\hline \multicolumn{8}{|l|}{ Qualitative trait } \\
\hline PPD (\%) & 2.29 & 3.27 & 3.29 & 4.32 & 1.02 & 0.4154 & 51.95 \\
\hline CRA (\%) & $59.81^{a b}$ & $53.57^{b}$ & $56.60^{\mathrm{ab}}$ & $60.40^{a}$ & 3.63 & 0.0399 & 5.96 \\
\hline CL (\%) & 29.77 & 29.10 & 30.03 & 35.13 & 1.11 & 0.3796 & 18.45 \\
\hline FC (kgf) & 3.34 & 3.10 & 3.54 & 3.87 & 0.61 & 0.6206 & 25.45 \\
\hline \multicolumn{8}{|c|}{ Composition $\left(\mathrm{g}^{\left.100 \mathrm{~g}^{-1}\right)}\right.$} \\
\hline Moisture & 70.13 & 69.77 & 70.32 & 70.11 & 0.37 & 0.7764 & 1.13 \\
\hline Protein & $25.62^{a}$ & $22.57^{b}$ & $23.19^{a b}$ & $23.67^{\mathrm{ab}}$ & 4.04 & 0.0290 & 5.55 \\
\hline Fat & 3.62 & 3.96 & 3.64 & 4.29 & 0.51 & 0.6834 & 24.68 \\
\hline Minerals & 1.34 & 1.48 & 1.39 & 1.40 & 0.34 & 0.7974 & 13.99 \\
\hline
\end{tabular}

D1: corn silage + concentrate; D2: corn silage + concentrate $+30 \mathrm{mg}^{2}$ rosemary extract kg BW-1; D3: corn silage + concentrate $+30 \mathrm{mg}$ green tea extract kg BW-1; D4: corn silage + concentrate $+30 \mathrm{mg}^{-1}$ oregano extract kg BW-1; TWL - thawing weight loss; WHC - water-holding capacity; CWL - cooking weight losses; MSF - meat shear force; a, ${ }^{\text {b }}$ Means followed by different letters in the same line differ from each other by the Tukey's test.

Meat with low water-holding capacity has greater losses of moisture and weight during storage. This also implies a loss of nutritional value due to released exudate, leading to drier meat with less tenderness. However, this did not occur in our study, given that water-holding capacity values were above $50 \%$.

By testing green tea inclusion $(2,4$, and $6 \mathrm{~g} \mathrm{~kg} \mathrm{DM}^{-1}$ ) in diets of 3-month-old Ujumqin lambs, Zhong et al. (2015) also found no effect on meat shear force, with an average of 2.36 kgf, which is lower than that observed by us (3.46 kgf). Since both are less than $8 \mathrm{kgf}$, both types of meat can be considered tender, which is commonly seen for lamb meat.

Regarding the centesimal composition, protein content in meat of lambs fed a diet without additives was higher $\left(25.62 \mathrm{~g}_{100 \mathrm{~g}^{-1}}\right.$ meat) than those fed diets with rosemary extract-enriched diets (22.57g $100 \mathrm{~g}^{-1}$ meat).

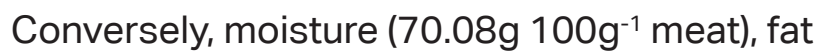
(3.88 $100 \mathrm{~g}^{-1}$ meat), and minerals $\left(1.40 \mathrm{~g} 100 \mathrm{~g}^{-}\right.$ ${ }^{1}$ meat) were not affected by the diets.

Likewise, when evaluating rosemary distillation residue inclusion, in the proportion of 60 and $87 \%$ in pellets supplied to Barbarine lambs slaughtered at 13 months of age, with an average body weight of $35.0 \mathrm{~kg}$, Yagoubi et al. (2018), also did not observe differences in the centesimal lamb meat composition in terms of moisture, fat, minerals, and protein.

Monteschio et al. (2019) evaluated the centesimal composition of meat from Nellore steers slaughtered at $356.6 \pm 32.6 \mathrm{~kg}$ receiving a control diet (without additive), a diet with rosemary essential oil $\left(4 \mathrm{~g}^{-1}\right.$ animal ${ }^{-1}$ day), a diet with a mixture of essential oils $\left(4 \mathrm{~g}^{-1}\right.$ animal ${ }^{-1}$ 
day), and a diet with a mixture of essential oils $\left(1.33 \mathrm{~g}^{-1} \mathrm{animal}^{-1}\right.$ day) associated with rosemary essential oil $\left(1.33 \mathrm{~g}^{-1}\right.$ animal ${ }^{-1}$ day). They did not observe any dietary effects on moisture

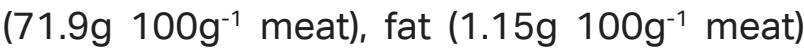
and mineral contents ( $1.13 \mathrm{~g} 100 \mathrm{~g}^{-1}$ meat) in beef from the Longissimus thoracis muscle of steers. However, unlike our study, these authors found no differences in protein content (22.56 $100 \mathrm{~g}^{-1}$ meat) due to the inclusion of essential oils in the diets.

According to these authors, the amount of $4 \mathrm{~g}$ animal $^{-1}$ day $^{-1}$ derived from the study of Rivaroli et al. (2016), who observed that $3.5 \mathrm{~g} \mathrm{animal}^{-1}$ day $^{-1}$ was not enough to change animal performance and meat quality. Benchaar et al. (2008) claimed that suitable amounts of essential oils to be incorporated in animal diets would range between 3 and 5 g day ${ }^{-1}$.

Table 5 describes the indexes, sums, and fatty acid ratios of meat from lamb fed diets with and without the inclusion of phytogenic additives, showing no effect of diets on such variables.

Table 5

Indexes, sums, and fatty acid ratios of meat from lambs fed diets with and without phytogenic additives inclusion.

\begin{tabular}{|c|c|c|c|c|c|c|c|}
\hline \multirow{2}{*}{ Parameter } & \multicolumn{4}{|c|}{ Experimental diet } & \multirow{2}{*}{$\mathrm{F}$} & \multirow{2}{*}{$\operatorname{Pr}>\mathrm{F}$} & \multirow{2}{*}{ CV (\%) } \\
\hline & D1 & D2 & D3 & D4 & & & \\
\hline$\Delta^{9}$ desaturase $16^{1}$ & 5.35 & 5.39 & 5.10 & 5.50 & 0.26 & 0.8535 & 13.65 \\
\hline$\Delta^{9}$ desaturase $18^{2}$ & 69.03 & 69.58 & 68.03 & 68.61 & 0.20 & 0.8917 & 4.45 \\
\hline Elongase $^{3}$ & 66.23 & 66.71 & 66.46 & 67.11 & 0.26 & 0.8552 & 2.40 \\
\hline Atherogenicity ${ }^{4}$ & 0.79 & 0.81 & 0.77 & 0.78 & 0.17 & 0.9122 & 11.46 \\
\hline Thrombogenicity ${ }^{5}$ & 6.93 & 6.18 & 7.23 & 7.12 & 1.12 & 0.3750 & 13.40 \\
\hline Hypocholesterolemic (h) ${ }^{6}$ & 45.54 & 45.71 & 45.42 & 45.76 & 0.04 & 0.9882 & 3.70 \\
\hline Hypercholesterolemic $(\mathrm{H})^{7}$ & 32.14 & 32.38 & 31.68 & 31.38 & 0.25 & 0.8570 & 5.95 \\
\hline h: $\mathrm{H}^{8}$ & 1.42 & 1.41 & 1.44 & 1.47 & 0.19 & 0.9032 & 8.45 \\
\hline UFA: SFA ${ }^{9}$ & 1.01 & 1.00 & 1.00 & 1.03 & 0.11 & 0.9531 & 8.28 \\
\hline MSFA: SFA ${ }^{10}$ & 0.87 & 0.88 & 0.85 & 0.88 & 0.14 & 0.9331 & 7.92 \\
\hline PSFA: SFA11 & 0.14 & 0.12 & 0.15 & 0.15 & 0.96 & 0.4384 & 21.31 \\
\hline
\end{tabular}

D1: corn silage + concentrate; D2: corn silage + concentrate + 30 mg rosemary extract kg BW ${ }^{-1}$; D3: corn silage + concentrate $+30 \mathrm{mg}$ green tea extract kg BW-1; D4: corn silage + concentrate $+30 \mathrm{mg}^{-1}$ ogano extract kg BW-1;

${ }^{1} 100[(16: 1 c 9) /(16: 1 c 9+16: 0)] ;{ }^{2} 100[(18: 1 c 9) /(18: 1 c 9+18: 0)] ;{ }^{3} 100[(18: 0+18: 1 c 9) /(16: 0+16: 1 c 9+18: 0+18: 1 c 9)] ;$ ${ }^{4}[(12: 0+(4 \times 14: 0)+16: 0)] /$ UFA; ${ }^{5}\left[(14: 0+16: 0+18: 0) /\left[(0,5 \times \Sigma M S F A)+\left(0,5 \times \Sigma n-6+(3 \times \Sigma n-3)+\left(\sum n-3 / \Sigma n-6\right)\right] ; 618: 1 n-7\right.\right.$ $+18: 1 n-9+18: 2 n-6+18: 3 n-3+18: 3 n-6+20: 3 n-6+20: 5 n-3) ;{ }^{7} 12: 0+14: 0+14: 1+16: 0+16: 1 ;{ }^{8}$ Hypocholesterolemic/ Hypercholesterolemic; ${ }^{9}$ Unsaturated fatty acids: saturated fatty acids; ${ }^{10}$ Monosaturated fatty acids: saturated fatty acids; ${ }^{11}$ Polyunsaturated fatty acids: saturated fatty acids. 
In a study to evaluate the effect of inclusion of carnosic acid on lamb diets, Jaworska, Czauderna, Przybylski and Rozbicka-Wieczorek (2016) also found no effect of including $0.1 \%$ carnosic acid on atherogenicity index (0.62), which is lower than ours (0.79). However, these authors reported a thrombogenicity index of 1.13 when carnosic acid and selenized yeast were included and 0.96 for the carnosic acid-enriched diet, both values are lower than ours (6.86).

In analyzing some fatty acid ratios in meat from Barbarine lambs, Yagoubi et al. (2018) also did not observe differences for the ratios MSFA: SFA (0.90) and PSFA: SFA (0.14). Lambs were slaughtered at 13 months of age, with an average body weight of $35.0 \mathrm{~kg}$, and received a control diet and a diet consisting of pellets with 60 and $87 \%$ of rosemary distillation residue during feedlot. On the other hand, the UFA: SFA ratio increased significantly with the addition of $60 \%$ rosemary extract (1.12) when compared to that of control (0.98). This is good because larger amounts of unsaturated fatty acids are desired over saturated ones. In contrast, the inclusion of $87 \%$ of rosemary extract increased the ratio less (1.05), not differing from those of control (0.98) or $60 \%$ rosemary inclusion (1.12).

Table 6 shows the lamb fattyacid profile. Unlike the usual prevalence of SFA in ruminant meat due to incomplete biohydrogenation, we observed $49.8 \%$ SFA against $50.2 \%$ UFA, of which $43.2 \%$ MSFA and 7.0\% PSFA. However, diets had no effect on SFA, MSFA (except for C18:1n7 cis-vaccenic), and PSFA.
Monteschio et al. (2019) also did not observe differences in the fatty acid profile of meat from Nellore steers slaughtered at $356.6 \pm 32.6 \mathrm{~kg}$ receiving control diet (without additive), a diet with rosemary essential oil (4g animal ${ }^{-1}$ day $\left.^{-1}\right)$, a diet with a mixture of essential oils ( $4 \mathrm{~g}_{\text {animal }}{ }^{-1}$ day $\left.^{-1}\right)$, and diet with a mixture of essential oils ( $1.33 \mathrm{~g}_{\text {animal }}{ }^{-1}$ day $^{-1}$ ) plus rosemary oil (1.33 $\mathrm{g}$ animal ${ }^{-1}$ day $\left.^{-1}\right)$, with values of $47.05 \%$ SFA and $52.41 \%$ UFA (47.35\% MSFA and $5.06 \%$ PSFA).

In a study to evaluate carnosic acid inclusion in lamb diets, Jaworska et al. (2016) observed higher MSFA deposition in diets added with carnosic acid $\left(6.86 \mathrm{mg}^{-1} \mathrm{~g}\right)$ than that of control diet $\left(5.69 \mathrm{mg}^{-1} \mathrm{~g}\right.$ ), but no differences for SFA (3.96 $\mathrm{mg}^{-1} \mathrm{~g}$ ) and PSFA (0.571 $\left.\mathrm{mg} \mathrm{g}^{-1}\right)$. In our study, no differences were observed in fatty acid contents (saturated and unsaturated) when including rosemary (a carnosic acid source) in lamb diets.

As for the sensory analysis (Table 7), no effect was observed on the parameters evaluated, with no adverse effects from additive concentrations since inclusions were higher than $6.6 \mathrm{mg}$, as already reported by Bellés et al. (2017). For these authors, meat flavor or odor can be intensified, changing the original product, and generating consumer rejection, thus emphasizing the importance of sensory analysis in studies of this nature. 
Table 6

Fatty acid profile $\left(\mathrm{g}^{\left.100 \mathrm{~g}^{-1}\right)}\right.$ of the Longissimus lumborum muscle of lambs fed diets with and without phytogenic additives.

\begin{tabular}{|c|c|c|c|c|c|c|c|}
\hline \multirow{2}{*}{ Parameter } & \multicolumn{4}{|c|}{ Experimental diet } & \multirow{2}{*}{$F$} & \multirow{2}{*}{$\operatorname{Pr}>\mathrm{F}$} & \multirow{2}{*}{ CV (\%) } \\
\hline & D1 & $\mathrm{D} 2$ & D3 & D4 & & & \\
\hline Saturated & 49.76 & 50.08 & 49.95 & 49.42 & 0.09 & 0.9651 & 4.16 \\
\hline C10:0 (capric) & 0.18 & 0.15 & 0.16 & 0.17 & 0.78 & 0.5228 & 17.45 \\
\hline C12:0 (lauric) & 0.19 & 0.19 & 0.15 & 0.20 & 0.17 & 0.9127 & 6.39 \\
\hline C14:0 (myristic) & 3.03 & 3.25 & 2.76 & 3.14 & 0.34 & 0.7989 & 25.77 \\
\hline C15:0 (pentadecanoic) & 0.28 & 0.28 & 0.27 & 0.26 & 0.09 & 0.9624 & 20.66 \\
\hline C16:0 (palmitic) & 27.47 & 27.46 & 27.38 & 26.59 & 0.54 & 0.6638 & 4.68 \\
\hline C17:0 (heptadecanoic) & 0.87 & 0.93 & 0.89 & 0.87 & 0.37 & 0.7774 & 11.39 \\
\hline C18:0 (stearic) & 17.64 & 17.71 & 18.26 & 18.10 & 0.09 & 0.9622 & 11.50 \\
\hline C20:0 (arachidic) & 0.09 & 0.08 & 0.08 & 0.09 & 2.77 & 0.0807 & 9.48 \\
\hline Monounsaturated & 43.08 & 43.95 & 42.56 & 43.33 & 0.44 & 0.7292 & 4.28 \\
\hline C14:1 (myristoleic) & 0.08 & 0.10 & 0.07 & 0.10 & 0.56 & 0.6518 & 52.95 \\
\hline C16:1 (palmitoleic) & 1.55 & 1.56 & 1.47 & 1.55 & 0.16 & 0.9198 & 15.02 \\
\hline C17:1 (heptadecenoic) & 0.48 & 0.52 & 0.47 & 0.50 & 0.45 & 0.7235 & 13.86 \\
\hline C18:1 (oleic) & 39.28 & 40.46 & 38.92 & 39.40 & 0.55 & 0.6541 & 4.66 \\
\hline C18:1n7 (cis-vaccenic) & $1.62 \mathrm{c}$ & $1.23 b$ & $1.55 a b c$ & $1.71 \mathrm{ac}$ & 5.36 & 0.0114 & 12.16 \\
\hline C20:1n9 (eicosenoic) & 0.07 & 0.07 & 0.07 & 0.08 & 0.25 & 0.8582 & 11.29 \\
\hline Polyunsaturated & 7.14 & 5.97 & 7.50 & 7.24 & 1.06 & 0.3978 & 19.41 \\
\hline C18:2 (linoleic) & 4.13 & 3.56 & 4.42 & 4.10 & 0.91 & 0.4622 & 19.15 \\
\hline C18:3n6 (linolenic) & 0.12 & 0.11 & 0.12 & 0.13 & 0.46 & 0.7153 & 14.55 \\
\hline C18:3n6 (linolenic) & 0.19 & 0.18 & 0.18 & 0.20 & 0.15 & 0.9271 & 20.83 \\
\hline C20:2 (eicosadienoic) & 0.04 & 0.03 & 0.04 & 0.04 & 1.09 & 0.3850 & 23.34 \\
\hline C20:2 (eicosatrienoic) & 0.13 & 0.11 & 0.15 & 0.14 & 0.87 & 0.4795 & 26.92 \\
\hline C20:4n6 (arachidonic) & 1.67 & 1.20 & 1.76 & 1.61 & 1.18 & 0.3523 & 29.83 \\
\hline C20:5n3 (eicosapentaenoic) & 0.06 & 0.05 & 0.07 & 0.09 & 0.78 & 0.5220 & 51.22 \\
\hline C22:4n6 (docosatetraenoic) & 0.16 & 0.11 & 0.17 & 0.16 & 1.19 & 0.3485 & 34.11 \\
\hline C22:5n3 (docosapentaenoic) & 0.19 & 0.17 & 0.21 & 0.22 & 0.49 & 0.6965 & 32.58 \\
\hline C22:6n3 (docosahexaenoic) & 0.05 & 0.04 & 0.05 & 0.08 & 2.31 & 0.1211 & 42.26 \\
\hline CLA (conjugated linoleic) & 0.39 & 0.40 & 0.33 & 0.49 & 1.24 & 0.3326 & 32.80 \\
\hline
\end{tabular}

$\mathrm{D} 1$ : corn silage + concentrate; D2: corn silage + concentrate + 30 mg rosemary extract kg BW ${ }^{-1}$; D3: corn silage + concentrate $+30 \mathrm{mg}$ green tea extract kg BW-1; D4: corn silage + concentrate +30 mg oregano extract kg BW-1. 


\section{Table 7}

Sensorial analysis of meat from Ile de France lambs fed diets with and without phytogenic additives.

\begin{tabular}{|c|c|c|c|c|c|c|c|}
\hline \multirow{2}{*}{ Parameter } & \multicolumn{4}{|c|}{ Experimental diet } & \multirow{2}{*}{$F$} & \multirow{2}{*}{$\operatorname{Pr}>\mathrm{F}$} & \multirow{2}{*}{ CV (\%) } \\
\hline & D1 & D2 & D3 & D4 & & & \\
\hline Color & 6.7 & 7.0 & 6.8 & 6.8 & 0.58 & 0.6255 & 19.76 \\
\hline Flavor & 7.3 & 7.2 & 6.7 & 6.6 & 3.35 & 0.0197 & 23.37 \\
\hline Softness & 7.8 & 7.5 & 7.5 & 7.2 & 2.10 & 0.1005 & 20.12 \\
\hline Global acceptance & 7.5a & 7.2ab & $6.8 a b$ & $6.6 b$ & 4.34 & 0.0053 & 22.95 \\
\hline
\end{tabular}

D1: corn silage + concentrate; D2: corn silage + concentrate +30 mg of rosemary extract $\mathrm{kg} \mathrm{BW}^{-1}$; D3: corn silage + concentrate $+30 \mathrm{mg}$ of green tea extract $\mathrm{kg} \mathrm{BW}^{-1}$; D4: corn silage + concentrate $+30 \mathrm{mg}^{\text {of oregano extract kg BW }}{ }^{-1}$.

\section{Conclusions}

The inclusion of phytogenic additives in lamb diets provided adequate qualitative characteristics for sheep meat. Despite the known positive effect of using antioxidants in lamb diets, phytogenic additives were not effective in reducing meat lipid oxidation. Thus, further studies should be conducted using different inclusion percentages to increase the shelf life of lamb meat, without harming qualitative traits, especially those related to sensory analysis.

\section{Acknowledgments}

To the Brazilian Council for Research and Development (CNPq) for granting the scholarship during the postdoctoral fellowship, to the Asteri Industria de Medicamentos Veterinarios Ltda. for donating the oreganobased phytogenic additives, and to the College of Agricultural and Veterinary Sciences (FCAV), UNESP, for supporting the development of this study with appropriate infrastructure and technical support.

\section{References}

Aouadi, D., Luciano, G., Valentina, B., Vasta, B., Nasri, S., Brogna, D. M. R., Ben Salem, H. (2014). The antioxidant status and oxidative stability of muscle from lambs receiving oral administration of Artemisia herba alba and Rosmarinus officinalis essential oils. Meat Science, 97(2), 237243. doi: 10. 1016/j.meatsci.2014.02.005

Association of Official Analytical Chemists (1995). Official methods of analysis (16nd ed.). Washington, D.C.: AOAC.

Augustin, M. A., Bhail, S., Cheng, L. J., Shen, Z., Oiseth, S., \& Sanguansri, L. (2015). Use of whole buttermilk for microencapsulation of omega-3 oils. Journal of Functional Foods, 19, 859-867. doi: 10.1016/j.jff. 2014.02.014

Bañón, S., Méndez, L., \& Almeida, E. (2012). Effects of dietary rosemary extract on lamb spoilage under retail display conditions. Meat Science, 90(3), 579-583. doi: 10.1016/j.meatsci.2011.09.020

Bellés, M., Alonso, V., Roncalés, P., \& Beltrán, J. A. (2017). A review of fresh lamb chilling and preservation. Small Ruminant 
Research, 146, 41-47. doi: 10.1016/j. smallrumres.2016.12.003

Benchaar, C., Calsamiglia, S., Chaves, A. V., Fraser, G. R., Colombatto, D., Mcallister, T. A., \& Beauchemin, K. A. (2008). A review of plant-derived essential oils in ruminant nutrition and production. Animal Feed Science and Technology, 145(1), 209-228. doi: 10.1016/j.anifeedsci.2007.04.014

Bessa, R. J. B (1999). Revalorização nutricional das gorduras dos ruminantes. Anais do Symposium Europeo - Alimentación en el Siglo, Badajoz, Espanha, 21.

Birtic, S., Dussort, P., Pierre, F. X., Bily, A. C., \& Roller, M. (2015). Carnosic acid. Phytochemistry, 115, 9-19. doi: 10.1016/j. phytochem.2014.12.026

Bligh, E. G., \& Dyer, W. J. (1959). A rapid method of total lipid extraction and purification. Canadian Journal of Biochemistry and Physiology, 37(8), 911-917. doi: 10.1139/059-099

Bohac, C. E., Rhee, K. S., \& Ono, K. (1988). Assessment of methodologies for calorimetric cholesterol assay of meats. Journal of Food Science, 53(6), 16421693. doi: 10.1111/j.1365-2621.1988.tb 07804.x

Bragagnolo, N., \& Rodriguez-Amaya, D.B.(2001). Determinação de colesterol em carne: comparação de um método colorimétrico e um método por cromatografia líquida de alta eficiência. Revista do Instituto Adolfo Lutz, 60(1), 53-57.

Cañeque,V., \& Sañudo, C. (2000). Metodologia para el estudo de la calidad de la canal y de la carne en rumiantes. Madrid: Instituto Nacional de Investigación y Tecnologia y Alimenticia.
Food and Agriculture Organization of the United Nations (2019). Production. Retrieved from http://faostat.fao.org/ beta/en/\#data/QA

Hamm, R. (1986). Functional properties of the myofibrillar system and their measurements. In Academic Press (Ed.). Muscle as food (pp. 135-199). New York, NY.

Hartman, L., \& Lago, R. C. A. (1973). Rapid preparation of fatty acid methyl esters. Laboratory Practice, 22(6), 475-494.

Jaworska, D., Czauderna, M., Przybylski, W., \& Rozbicka-Wieczorek, A. J. (2016). Sensory quality and chemical composition of meat from lambs fed diets enriched with fish and rapeseed oils, carnosic acid and selenocompounds. Meat Science, 119, 185-192. doi: 10.1016/j.meatsci.2016.05.003

Jiang, J., \& Xiong, Y. L. (2016). Natural antioxidants as food and feed additives to promote health benefits and quality of meat products: a review. Meat Science, 120, 107-117. doi: 10.1016/j. meatsci.2016.04.005

Justo, O. R., \& Moraes, A. M. (2008). Avaliação do potencial antioxidante de extratos ativos de plantas obtidos por extração com fluido supercrítico. Química Nova, 31(7), 1699-1705. doi: 10.1590/S010040422008000700019

Koohmaraie, M., Shackelford, S. D., \& Wheeler, T. L. (1998). A base biológica da maciez da carne bovina e abordagens potenciais para seu controle e previsão. Anais Repensando a Pecuária de Corte: Experiências Internacionais, Uberaba, MG, Brasil. 
Malau-Aduli, A. E. O., Siebert, B. D., Bottema, C. D. K., \& Pitchford, W. S. (1997). A comparison of the fatty acid composition of triacylglycerols in adipose tissue from Limousin and Jersey cattle. Australian Journal of Agricultural Research, 48(5), 715-722. doi: 10.1071/A96083

Monteschio, J. O., Vargas, F. M., Jr., Almeida, F. L. A., Pinto, L. A. M., Kanekoc, I. N., Almeida, A. A.,... Prado, I. N. (2019). The effect of encapsulated active principles (eugenol, thymol, and vanillin) and clove and rosemary essential oils on the structure, collagen content, chemical composition, and fatty acid profile of Nellore heifers muscle. Meat Science, 155, 27-35. doi: 10.1016/j.meatsci.2019.04.019

Moraes, M. A. C. (1993). Métodos para avaliação sensorial dos alimentos. Campinas: FEA/ UNICAMP.

Morán, L., Giráldez, F. J., Panseri S., Aldai, N., Jordán, M. J., Chiesa, L. M., \& Andrés, S. (2013). Effect of dietary carnosic acid on the fatty acid profile and flavour stability of meat from fattening lambs. Food Chemistry, 138(4), 2407-2414. doi: 10.1016/j.foodchem.2012.12.033

National Research Council (2007). Nutrient requirements of small ruminants: sheep, goats, cervids, and new camelids. Washington: The National Academic Press.

Nieto, G., Díaz, P., Bañón, S., \& Garrido, M. D. (2010). Dietary administration of ewe diets with a distillate from rosemary leaves (Rosmarinus officinalis L.): Influence on lamb meat quality. Meat Science, 84(1), 2329. doi: 10.1016/j.meatsci.2009.08.001
Pamplona, R., \& Costantini, D. (2011). Molecular and structural antioxidant defenses against oxidative stress in animals. American Journal of PhysiologyRegulatory, Integrative and Comparative Physiology, 301(4), 843-863. doi: 10.1152/ ajpregu.00034.2011

Pikul, J., Leszczynski, D. E., \& Kummerow, F. A. (1989). Evaluation of three modified TBA methods for measuring lipid oxidation in chicken meat. Journal of Agricultural of Food Chemistry, 37(5), 1309-1313. doi: 10.1021/jf00089a022

Rivaroli, D. C., Guerrero, A., Valero, M. V., Zawadzki, F., Eiras, C. E., Campo, M. M., \& Prado, I. N. (2016). Effect of essential oils on meat and fat qualities of crossbred young bulls finished in feedlots. Meat Science, 121, 278-284. doi: 10.1016/j. meatsci.2016.06.017

Sallam, S. M. A., Abdelgaleil, S. A. M., \& Bueno, I. C. S. (2011). Effect of essential oils on ruminal fermentation, microbial population and methane emission in vitro. Cahiers Options Mediterraneennes, 9, 149-156. Retrieved from http://om.ciheam.org/om/ pdf/a99/00801549.pdf

Silva, A. G., Sobrinho. (2008). Produção de carne ovina. Jaboticabal: FUNEP.

Silva, A. G., Sobrinho, Kadim, I. T., \& Purchas, R. W. (2003). Effect of genotypes and age on carcass and meat quality characteristics of ram lambs. Journal of Agricultural and Marine Sciences, 8, 73-78.

Simitzis, P. E., Deligeorgis, S. G., Bizelis, J. A., Dardamani, A., Theodosiou, I., \& Fegeros, K. (2008). Effect of dietary oregano oil supplementation on lamb meat characteristics. Meat Science, 79(2), 217223. doi: 10.1016/j.meatsci.2007.09.005 
Souza, X. R., Bressan, M. C., Pérez, J. R. O., Faria, P. B., Vieira, J. O., \& Kabeya, D. M. (2004). Efeitos do grupo genético, sexo e peso ao abate sobre as propriedades físico-químicas da carne de cordeiros em crescimento. Ciência e Tecnologia de Alimentos, 24(4), 543-549. doi: 10.1590/ S0101-20612004000400011

Statistical Analysis System Institute (2003). SAS/STAT user's guide: statistics version 6.4 (Vol. 2). Cary, NC: SAS Inst.

Ulbricht, T. L. V., \& Southgate, D. A. T. (1991). Coronary heart disease: seven dietary factors. Lancet, 338(8773), 985-992. doi: 10.1016/0140-6736(91)91846-M

Van Wyk, J. A., \& Bath, G. F. (2002). The FAMACHAC system for managing haemonchosis in sheep and goats by clinically identifying individual animals for treatment. Veterinary Research, 33, 509529. doi: $10.1051 /$ vetres:2002036

Wheeler, T. L., \& Koohmaraie, M. (1999). The extent of proteolysis is independent of sarcomere length in lamb Longissimus dorsi and Psoas major. Journal of Animal Science, 77(9), 2444-2451.
Yagoubi, Y., Joy, M., Ripollc, G., Mahouachid, M., Bertolínc, J. R., \& Atti, N. (2018). Rosemary distillation residues reduce lipid oxidation, increase alphatocopherol content and improve fatty acid profile of lamb meat. Meat Science, 136, 23-29. doi: 10.1016/j. meatsci.2017.10.007

Zanette, P. M., \& Neumann, M. (2012). Confinamento como ferramenta para incremento na produção e na qualidade da carne de ovinos. Ambiência, 8(2), 415-426. doi: 10.5777/ambiencia.2012.02.03rb

Zen, S., Santos, M. C., \& Monteiro, C. M. (2014). Evolução da caprino e ovinocultura. Boletim Ativos da Pecuária de Caprino e Ovinocultura, 9(1), 1-3.

Zhong, R. Z., Li, H. Y., Fang, Y., Sun, H. X., \& Zhou, D. W. (2015). Effect of dietary supplementation with green tea polyphenols on digestion and meat quality in lambs infected with Haemonchus contortus. Meat Science, 105, 1-7. doi: 10.1016/j.meatsci.2015.02.003 